\title{
Norepinephrine, DL-
}

National Cancer Institute

\section{Source}

National Cancer Institute. Norepinephrine, DL-. NCI Thesaurus. Code C62098.

A synthetic phenylethylamine that mimics the sympathomimetic actions of the endogenous norepinephrine. Norepinephrine acts directly on the alpha- and betaadrenergic receptors. Clinically, norepinephrine is used as a peripheral vasoconstrictor that causes constriction of arterial and venous beds via its alpha-adrenergic action. It is also used as a potent inotropic and chronotropic stimulator of the heart mediated through its beta-1 adrenergic action. 